\title{
Business Model Analysis Badong Costume Smes Gandu Village, Temanggung District Using the Canvas Model Business Approach
}

\author{
Dina Lestari Purbawati ${ }^{1}$, Agung Budiatmo ${ }^{2}$, Ilham Ainuddin ${ }^{3}$, Nurul Imani Kurniawati ${ }^{4}$ \\ \{dinapyu@gmail.com ${ }^{1}$ \} \\ Universitas Diponegoro, Indonesia ${ }^{1,2,3.4}$
}

\begin{abstract}
This research is motivated by the importance of encouraging Indonesian culture in the international eyes and improving the welfare of local communities. Badong Costume as a traditional Indonesian art product have good potential to be able to penetrate the global market. At present, SMEs who make badong Costume in Gandu Village, Tembarak Subdistrict, Temanggung Regency, their markets are limited to the subdistrict area and have not yet made much economic contribution to businesses. This increase can be achieved by using the Business Model Canvas. The purpose of this research is to determine the readiness of the Badong Costume SME business (analyzed using the canvas model business approach). The Business Model Canvas explains about 9 building blocks that show how companies are more productive. This type of research is a descriptive study with qualitative methods. The results of this study indicate that SMEs Badong Shirt has not implemented the Business Model Canvas properly. Based on the Importance Performance Analysis Matrix, SME Badong Costume has a lack of management. This causes these SMEs to become unproductive. The findings are used to formulate a general strategy that can be used in the traditional arts industry.
\end{abstract}

Keywords: Badong Costume, Traditional Art, Business Canvas Model

\section{Introduction}

Indonesia consists of various ethnic, cultural, racial, religious beliefs and others. According to Central Statistics Agency (BPS) in 2010, there were 1,211 regional languages in Indonesia. The Ministry of Home Affairs, based on reports from regional heads of governors/regents/mayors in 2004, stated that there were 7,870 islands in Indonesia that already had names and 9,634 islands that did not yet have names. And there are 714 tribes in Indonesia according to the President's speech in Barus, Central Tapanuli, North Sumatra.

The diversity of Indonesian culture is not accompanied by worldwide recognition of the Indonesian culture. Until now only recorded puppets, keris, batik, angklung, subak and saman dance as native Indonesian culture that has been established by UNESCO. Indonesia needs to promote its culture, both through tourism and its art products.

Basically, almost every region in Indonesia has their own traditional Costume. One of them is badong Costume, where the Costume in Central Java are used as costume to perform traditional cultural arts. Badong Costume precisely came from the area of Magelang, Borobudur to be exact. For several years the art spread to Temanggung.

In Temanggung, precisely in Gandu Village, Tembarak Subdistrict, there are several SMEs that produce these badong Costume. In addition to providing positive encouragement to Indonesia's native culture, the production of these badong Costume also greatly helps citizens 
in improving their welfare. But until now, MSME productivity is still very low. MSME profitability is still very low, so it is less than optimal in providing benefits to residents.

\subsection{Formulation of the problem}

Gandu Village's local art products in the form of badong Costume have great potential to increase profitability through business effectiveness and efficiency. However, the potential of local art products in the Gandu Village has not been seriously worked on until now. Efforts that have been made by residents and village government are currently only able to expand markets in the local area.

Seeing the phenomena and problems above, the research question that can be formulated in this research is How is the readiness of the Badong SME business (analyzed using the canvas model business approach?

\subsection{Research Objectives and Benefits}

The purpose of this study is to determine the readiness of the Badong Costume SME business (analyzed using the canvas model business approach).

\section{Theoretical Framework}

\subsection{Understanding SMEs}

SMEs have different meanings in several agencies. Among others, according to the UU Republic of Indonesia No 20, 2008 Concerning SMEs

a. Micro Business is a productive business, that:

1) net asset $<\operatorname{Rp} 50.000 .000$; or

2) annual sales at most three hundred million rupiah.

b. Small Business (SB) is a productive business that stands alone.

1) net asset of $\geq \mathrm{Rp} 50.000 .000$ - Rp 500.000.000; or

2) annual sales results of $\geq$ Rp. 300,000,000 - Rp 2.500.000.000

c. Medium Business is a productive business, that:

1) net asset of $\geq$ Rp.500.000.000 - Rp 10.000.000.000;

2) annual sales of $\geq$ Rp. 2,500,000,000 - Rp 50.000.000.000.

Whereas the BPS provides of SMEs a definition based of the quantity' labor. Small businesses have labor of $5-19$ peoples, while the medium businesses have labor of $20-99$ peoples.

\subsection{Business Model}

Osterwalder and Pigneur [1] state that BMC is the same perception for visualizing, evaluating, and changing the model of business. On Business Model Generation, Osterwalder and Pigneur [1] explain that this BMC can be a shared perception that makes it possible to manipulate and describe the model of business easily and then create updated strategic alternatives [2][3]. Without language in common, it would be difficult to be able to make assumptions about a business model and innovate successfully [4][5]. 


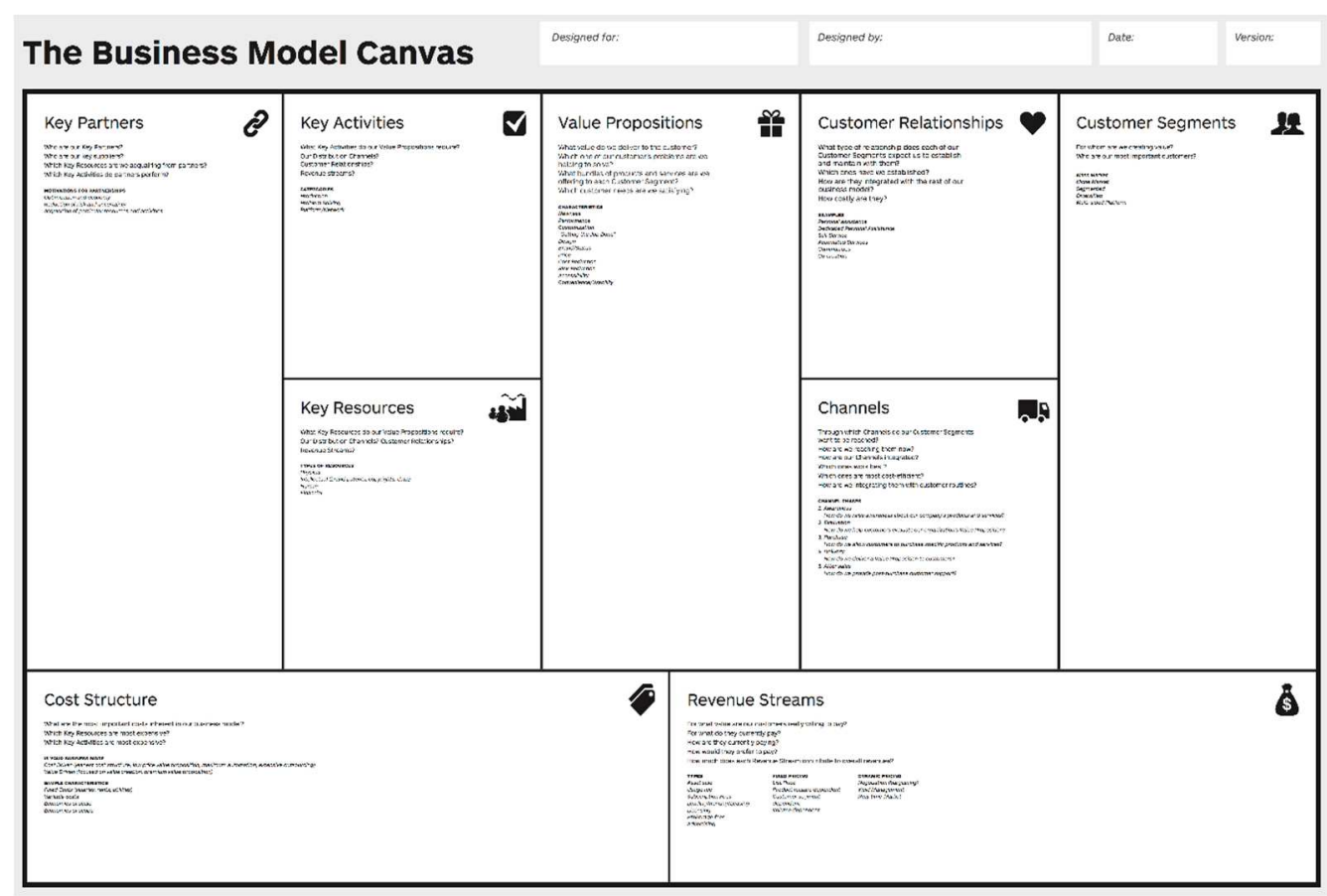

Fig. 1. Nine Blocks [1].

\subsubsection{Customer Segmentation}

Osterwalder and Pigneur [1] say building blocks of customer segments. Customer segments explain how companies choose the most potential customer segments to be chosen. As stated by Osterwalder and Pigneur [1] that customers are the core of business. Without customers, no company can survive (no business continuity). To be able to satisfy the customer easily, companies can group customers into different segments based on their similarity, and a business model can describe on several customer segments.

According to Kotler [6] dividing the customer market into 5 namely:

1) Consumer Market.

2) Industrial Market.

3) Market resellers.

4) Government market.

5) International markets.

The market demand perspective can be integrated in the perspective of supply through a strategic market segmentation process with the following steps:

1) Segmentation Stage

a) Segmenting the market using variables demand, customer needs, the benefits sought (benefit sought), the solution to the problems encountered, the situation of use and others.

b) Describe the identified market segments using variables that can help the company understand how to serve the customer's needs (for example, supplier switching costs, shopping costs, geographic location, customer size, purchasing power, price 
sensitivity and so on) and how to communicate with customers (for example , preferences and use of media, attitudes, activities, interests, opinions and others).

2) Targeting Phase

a) Evaluate the attractiveness of each segment using variables that can quantify the possible demand from the segment (for example, the growth rate of the segment concerned), the cost of serving each segment (for example, distribution costs), the costs of producing products and services that customers want (for example, costs production and product differentiation), and the compatibility between the company's core competencies and target market opportunities.

b) Select one or more target segments to be served based on the potential of the segment and its suitability with the corporate strategy.

3) Positioning Stage

Identifying the concept of positioning for company products and services that are attractive to target customers and compatible with the company's expected image.

There are many customers, needs and products that shape a market. Marketing must determine which segments offer the best opportunities. Consumers can be grouped and served in various ways based on geographical, demographic, psychographic, and behavioral factors [7]. This means that each company must choose and determine which segments are really potential and best to be served so that the company can reach the right segments from the various available market segments. As stated by Kotler [7] the process of dividing markets into different groups of buyers who have different needs, characteristics, or behaviors, which may require a separate product or marketing program is called market segmentation.

\subsubsection{Value Propositions}

Osterwalder et.al [1] Value Propositions describe how the company provides (the combination of products and services) the best value to its customers in accordance with the existing value proposition in the company. By creating superior customer value, companies create customers who are very satisfied and remain loyal, and are willing to buy more [7]. It can provide benefits for companies in the future because they already have loyal customers.

\subsubsection{Channels (Channels)}

Channel building blocks describe the way the company reaches and communicates its customers to provide proposition of value [1]. These Channels explain how companies reach consumers by communication channels; the distribution used by companies. The communication, sales channels and distribution are relationship between the customer and the customer. Channels are points for touching customer that play an important role in every moment they experience. Most companies use intermediaries or distribution channels to get their products to market.

\subsubsection{Customer Relationship}

Kotler [6] describes customer relationship management, namely managing detailed information about individual customers and carefully managing customer "touch points" to maximize customer loyalty. Customer relations are used to understand customers better, so companies can increase the value of service to customers and further develop deeper customer relationships. 


\subsubsection{Revenue Streams}

Osterwalder and Pigneur [1] state that Revenue flow describes the profit generated by the company from the customer (costs must reduce revenue to generate revenue). Revenue flow is a key factor that needs to be optimized so that the company gets the maximum profit. If the customer is the core of the business model, the revenue stream is the pulse. When we talk about income, we inevitably also talk about how to get profit or profit. Profitability is the company's ability to gain profit from its business. To optimize profits and streamline earnings, we must link net income to the assets used to generate profits.

\subsubsection{Main Resources (Key Resources)}

Osterwalder et.al [1] state that the main resource of a business is the company's assets. The main resources are assets that are used by companies to support their business activities. Every model of business requires the key resources. These resources might offer and create value proposition of companies, reach of the market, maintain customer, and earn revenue. The main resources can be intellectual, physical, human or financial. Main resources could be leased or owned by a company and obtained from main partners.

\subsubsection{Key Activities}

Osterwalder and Pigneur [1] said that Key activities are the main activities in the company so that they can run well. Like key resources, key activities are also needed to create and provide value propositions, reach markets, maintain customer relationships, and make a profit. Each key activity between companies varies depending of the business type being carried out and the type of business model. So the key activities are all business activities that are important for the company to drive the business carried out in order to achieve the company's goals in the future.

\subsubsection{Key Partnership}

Key partnerships are main building blocks of partnership describing the network of $d$ partners that make the business model works [1]. One of the partnerships that can be invited by business people in the company is marketing channels and distributors. So the key partnership is a partnership relationship made by the company to other parties to support the business activities carried out. In addition to implementing good customer relationship management, marketers must also carry out relationship management partnership (partner relationship management) is also good.

\subsubsection{Cost Structure}

In the cost structure usually describes the costs incurred by the company in carrying out its business activities. Based to Osterwalder et.al [1] these cost structure blocks explain cost priorities that arise when running business processes. Creating value for consumers, providing value to consumers, maintaining good relations with consumers, and processing the income from these various processes, incurs many costs. Calculation of these costs is relatively easy after the main resource. The cost structure basically explains about the costs that must be 
incurred to carry out business activities carried out. However, some business models are more driven in terms of cost than other business models. It is normal for every business model to minimize costs. However, a low cost structure is more important for some business models than for other business models. Therefore, it would be very useful if the cost structure of the business model is divided into 2 classes, which are cost driven and value driven. Many business models are between these two extremes.

1) Cost Driven (cost driven)

The cost driven business model focuses on minimizing costs. This approach aims to create and maintain a cost structure as lean as possible, using value propositions at low prices, maximum automation, and outsourcing extensively.

2) Value driven

Some companies care less about the cost implications of designing certain business models, and focus on value creation. Premium value propositions and high-level personal services typically characterize value driven business models.

\section{Research Methodology}

This research uses descriptive research type. Descriptive research is designed to provide a systematic overview of scientific information. Descriptive research focusesm on the systematic explanation of the facts obtained [8].

\begin{tabular}{|c|c|c|}
\hline No & Variable & Questions \\
\hline 1 & Key of Partners & $\begin{array}{l}\text { a. Key business partners } \\
\text { b. Key business supplier } \\
\text { c. The main resource is business obtained from } \\
\text { partners } \\
\text { d. The main activity carried out by partners }\end{array}$ \\
\hline 2 & Key of Activities & $\begin{array}{l}\text { a. Main activities do business value propositions } \\
\text { b. Business distribution channels } \\
\text { c. Customer relationships } \\
\text { d. Revenue streams }\end{array}$ \\
\hline 3 & Key of Resources & a. Main resources do business value propositions \\
\hline 4 & Propositions of Value & $\begin{array}{l}\text { a. Value delivered to customer } \\
\text { b. What problems from customers can we help } \\
\text { solved } \\
\text { c. a combination of services and products offered in } \\
\text { all customer segments } \\
\text { d. Customer necessary that we satisfy }\end{array}$ \\
\hline 5 & Customer Relationships & $\begin{array}{l}\text { a. The types link that are expected by each of } \\
\text { customer segments be maintained and built } \\
\text { b. Customer Relationship have established } \\
\text { c. Integration model } \\
\text { d. Cost }\end{array}$ \\
\hline 6 & Segments of Customer & $\begin{array}{l}\text { a. Segment are we building value } \\
\text { b. Most significant customers }\end{array}$ \\
\hline 7 & Channels & $\begin{array}{l}\text { a. Channels to reach customers } \\
\text { b. Present channels } \\
\text { c. Channels integration } \\
\text { d. Best channels integration }\end{array}$ \\
\hline
\end{tabular}




\begin{tabular}{|l|l|ll|}
\hline & & e. & The most cost-efficient channels \\
& f. & Channels integration with routines of customer \\
\hline 8 & Structure of Cost & a. & The most significant costs inherent on business \\
& & b. & Model expensive in business model \\
& & c. & Most expensive in business model \\
\hline 9 & Revenue Streams & a. & Value for customers really want to pay \\
& & b. & Present value \\
& & c. & Present customer paying process \\
& & d. & Customer paying process they prefer to pay \\
& e. & Revenue stream contribute to overall revenues \\
\hline
\end{tabular}

There were three informants in this study, namely the village government, the chairman of the SME Baju Badong, and Baju Badong consumer. All three will be interviewed separately.

\section{Results and Discussion}

\subsection{Key Partners}

Key partnerships are the main building blocks of partnership which gives an overview of the network of business partners and suppliers, so that a business can run well. The company forms a partnership with various objectives, and the partnership provides the basis for the company's business model. At the Badong SME Costume, suppliers of materials for making badong Costume from various locations around Central Java, but for peacock feather materials obtained from Probolinggo, East Java.

Marketing conducted by SMEs Badong Costume is currently only through word of mouth, and even then, it is limited to the area around Temanggung Regency. Until now the Badong Shirt sales market is only around Temanggung Regency, but it does not open up the possibility of products being sold, sold back to markets outside Temanggung Regency.

\subsection{Key Activities}

Key activities illustrate the main thing that should be done by a company so that its business model is effective. Key activities are all business activities that are important for a company to drive its business to achieve the company's goals in the future. The key activity of Badong SMEs is that in the production process, it requires special hands from experienced badong shirt craftsmen, because if it is done by inexperienced people, the products produced will have poor quality and inaccurate workmanship. This will certainly have an impact on decreasing customer satisfaction, and in-efficiency in the production process.

\subsection{Key Resources}

Key resources describe the main assets needed for an effective business. Financial resources owned by SME Badong Costume are currently very limited, their capital does not reach IDR 20.000.000, and even then most of it is assistance from the local government and grants from various charitable organizations. 


\subsection{Value Propositions}

The Building Blocks on value propositions describe the fusion of services and products are capable of creating value for customer segments. The SME Market of Badong Costume is a perpetrator and observer of the art of Badong Dance in the vicinity of Temanggung Regency. SME Badong Costume is the only craftsman in the region, so that it is able to dominate the market segment in the area.

\subsection{Customer Relationship}

Customer relationship management, namely managing detailed information about individual customers and carefully managing customer "touch points" to maximize customer loyalty. SME Badong Costume has a simple customer relationship management, that is, it only takes a few moments to call by phone or visit its customers. And if a product that has been sold is damaged, consumers will be directed to send it to the Badong SME Shirt so that it can be repaired.

\subsection{Customer Segments}

Building blocks of customer segments describe a different category of people the company desirable to serve or reach. The market segmentation of UMM Badong Costume is currently the perpetrators and observers of the Badong Dance art around Temanggung Regency, but it is expected that in the future it will be able to expand the market to the level of Central Java Province.

\subsection{Channels}

Channel building blocks describe how companies communicate with their customers and reach these customers, to be able to provide the value of their products to their customers. SME Badong Costume distributes its products directly by land because the market area is not extensive.

\subsection{Cost Structure}

Cost structure building blocks explain the importance of the costs that arise when operating certain business models. Most of the costs incurred by SMEs Badong Costume are on the material of Badong Costume itself. Both some types of fabric, and knick knacks obtained from around Central Java with a relatively cheap price. As for the peacock feather, it is obtained at a high price of up to IDR 10.000.000 in one purchase. So the price of a set of badong Costume for a full team is almost IDR 15.000.000. Badong Clothing SMEs doesn't really care about the costs they have spent. And they only focus on the process of creating value in their products. This can also be seen in the financial management process of the Badong SMEs, they do not document the company's finances. All is only based on memory. 


\subsection{Revenue Streams}

The profit of UMKM Badong Costume is only obtained from product sales. The sale of products is usually only one to two times a month. in a month. On average, they can earn IDR 25.000.000 per month in revenue. Even then, for some consumers, the payment is made on a tempo basis (partially delayed payment). They were able to make a profit of IDR 4.500.000.

\section{Conclusion}

The above description shows that SME Badong Costume are currently not well developed. Barriers experienced include the small capital and the difficulty of obtaining additional capital, some raw materials instead and are difficult to obtain, relatively narrow (local) market share, and poor financial management.

These things need to be fixed immediately to be able to develop Badong Costume SMEs. Given the lack of competitors, this is a golden opportunity for SMEs Badong Costume to be able to expand the market and increase sales.

\section{References}

[1] A. Osterwalder and Y. Pigneur, "Business model Generation (terjemahan)," Jakarta PT. Elex Media Komputindo, 2012.

[2] H. Umar, Strategic management in action. Gramedia Pustaka Utama, 2001.

[3] M. P. Sondang, "Siagian, Manajemen Stratejik," Cetakan pertama. Jakarta. Bumi Aksara, 1995.

[4] R. Kalakota and M. Robinson, E-business 2.0: Roadmap for Success. Addison-Wesley Longman Publishing Co., Inc., 2001.

[5] R. Pambudi, "Business Model Canvas: Uji Kelayakan Pada Bisnis Ritel (Studi Pada CV. Basic Group Computer." Fakultas Ilmu Sosial dan Ilmu Politik, 2015.

[6] P. Kotler, Marketing management: The millennium edition, vol. 199. Prentice Hall Upper Saddle River, NJ, 1999.

[7] P. Kotler et al., Marketing management-trženjsko upravljanje: analiza, načrtovanje, izvajanje in nadzor. Slovenska knjiga, 1996.

[8] A. Sanusi, "Metodologi penelitian bisnis.” Jakarta: Salemba Empat, 2011. 